\title{
Epigean ant communities in Atlantic Forest remnants of São Paulo: a comparative study using the guild concept
}

\author{
Luciano Pacelli Medeiros Macedoํㅡ, Evoneo Berti Filho² \& Jacques Hubert Charles Delabie ${ }^{3}$
}

${ }^{1}$ Laboratório de Biotecnologia, Campus Ipanguaçu, Instituto Federal de Educação, Ciência e Tecnologia do Rio Grande do Norte, 59508-000 Ipanguaçu-RN, Brasil. luciano.macedo@ifrn.edu.br

${ }^{2}$ Departamento de Entomologia, Fitopatologia e Zoologia Agrícola, Escola Superior de Agricultura "Luiz de Queiroz”, Universidade de São Paulo, Caixa Posta1 9, 13418-900 Piracicaba-SP, Brasil. eberti@esalq.usp.br

${ }^{3}$ Laboratório de Mirmecologia, Centro de Pesquisas do Cacau, Caixa Postal 7, 45600-000 Itabuna-BA, Brasil. delabie@cepec.gov.br

\begin{abstract}
Epigean ant communities in Atlantic Forest remnants of São Paulo: a comparative study using the guild concept. The guilds constitute a valuable ecological tool, because they allow conducting comparisons among environments under different conditions. The ants can be used as ecological indicators, mainly for the monitoring of degraded forest areas. The aim of this research was to study guild organization among the epigeous Formicidae living in Atlantic forest remnants of the State of São Paulo, Brazil. Ant collections were performed in three distinct Atlantic forest biome areas: arboreal littoral vegetation ("restinga") (Cananéia), semideciduous seasonal forest (Piracicaba) and dense ombrophylous forest (Pariquera-Açu). After identification, the ants were grouped into guilds, based on the ecological attributes of behavior and habit, according to the literature. Nine guilds were found; the semideciduous seasonal forest ecosystem presented eight of them, followed by the arboreal sandbank (7) and dense ombrophylous forest (6). The guilds found were: litter omnivorous and scavengers, granivorous species, specialist predators living in litter and soil, litter generalist predators, subterranean mealybug-dependent species, army ants, dominant or subdominants arboreal, that occasionally forage on the ground, soil or litter dominant and fungus-growers, using feces and insect body fragments. The guilds found can be used in the monitoring of the mirmecofauna in the Atlantic Forest biome, supplying insights for further ecological studies.
\end{abstract}

KEYWORDS. Ecological bioindicators; ecosystems; environmental monitoring; Formicidae; Hymenoptera.

RESUMO. Comunidades de formigas epígeas em remanescentes da Mata Atlântica do Estado de São Paulo: um estudo comparativo utilizando o conceito de guildas. As guildas constituem-se em uma valiosa ferramenta ecológica, pois permitem realizar comparações entre ambientes em diferentes condições. As formigas podem ser utilizadas como indicadores ecológicos, principalmente para o monitoramento de áreas florestais degradadas. O objetivo deste estudo foi agrupar em guildas os Formicidae epígeas, coletados em remanescentes da Mata Atlântica do Estado de São Paulo. As coletas ocorreram em três áreas distintas do bioma Mata Atlântica: restinga arbórea (Cananéia), floresta estacional semidecídua (Piracicaba) e floresta ombrófila densa (Pariquera-Açu). As formigas foram identificadas e agrupadas em guildas, com base nos atributos ecológicos de comportamento e hábito, de acordo com a literatura. As formigas foram agrupadas em nove guildas, sendo que o ecossistema floresta estacional semidecídua apresentou oito destas, seguido da restinga arbórea (7) e da floresta ombrófila densa (6). As guildas encontradas foram: espécies onívoras, espécies granívoras, espécies predadoras especialistas de serapilheira e do solo, espécies predadoras generalistas de serapilheira, formigas subterrâneas dependentes de honeydew, formigas que fazem correições, formigas arborícolas dominantes ou subdominantes, que ocasionalmente forrageiam no chão, formigas dominantes de solo ou serapilheira e formigas cultivadoras de fungo, utilizando fezes e cadáveres de insetos. As guildas encontradas poderão ser utilizadas em monitoramento da mirmecofauna no bioma Mata Atlântica, fornecendo subsídios para futuros estudos ecológicos.

PALAVRAS-CHAVE. Bioindicadores ecológicos; ecossistemas; Formicidae; Hymenoptera; monitoramento ambiental.

The idea that some species can be used as an environmental quality indicator is older than ecology as a science (Beeby 1993). According to Louzada et al. (2000), bioindicators are live organisms or biological processes used to evaluate the responses of the ecosystem to environmental disturbances, and they are frequently associated with the use of the earth by man. For instance, several groups of invertebrate animals have been used as bioindicators of the success of mine rehabilitation, because they occupy specialized niches, supplying information on the area according to their presence or absence (Majer 1981). The ant group, one of the most successful of all the invertebrate animals (Wilson 1987), has been evaluated for many years as a potential tool as an ecological indicator, especially in Australia, with the objective of evaluating the impact of forest practices under the effect of the fire (York 1994). One of the main reasons for that is that those insects are locally abundant and species rich, they possess several specialized taxa, are relatively predictable, easily sampled and identified, and are sensitive to changes in the environmental conditions (Majer 1983).

In Brazil, several studies have been conducted using ants as bioindicators (Majer 1992, 1996; Vasconcelos 1999; Vasconcelos et al. 2001; Ramos et al. 2003; Delabie et al. 2006). The first studies were carried out in areas disturbed by bauxite extraction in Poços de Caldas, MG (Majer 1992) and in Trombetas, PA (Majer 1996). The ants were also used 
to determine the effects of the fragmentation and isolation of the Amazonian forest (Vasconcelos 1999; Vasconcelos et al. 2001), to evaluate the impact of sylviculture practices in eucalyptus reforestations and as agrarian and natural environmental use bioindicators (Ramos et al. 2003).

The use of ants as biological indicators, as well as of any other organism, requires previous knowledge of the ecological factors determining the structure and composition of their communities (Andersen 1997). According to that author, seeking to facilitate the studies on ants, the environmentalists can join the species in functional groups or guilds (those concepts are usually confused, being considered synonyms by some authors). The pioneers of this kind of study in ants are mainly Andersen (1991, 1992, 1997), in Australia, while in Brazil, the first studies making references to the guild or functional group of Formicidae was Delabie et al. (2000) in the Atlantic Forest and Silvestre et al. (2003) in the "cerrado" biome. More recent publications referred to ant guilds in Brazil are those of Brandão et al. (2009) and Silva \& Brandão (2010).

The term guild, adopted by the environmentalists, makes an analogy to the medieval crafts organizations, that gathered individuals with the same ability or who depended on the same form of sustenance, as for instance, artisans, goldsmiths, carpenters or millers (Elton 1927). For Root (1967), extending this to ecology, the term guild defines a group of species that explore the same class of environmental resources, showing similar exploration patterns of those resources. The description of functional groups or guilds has shown to be a valuable tool allowing making comparisons among environments under different conditions. That type of model has been used with success in different areas of the world in forest area monitoring programs (Lawton et al. 1998) and in relation to different types of soil use (Bestelmeyer \& Wiens 1996).

The present study aimed to compare Atlantic Forest remnants in the State of São Paulo using the guild concept to epigeous Formicidae.

\section{MATERIAL AND METHODS}

The study of the myrmecofauna was conducted in three fragments of the Atlantic Forest of the State of São Paulo, located in the counties of Cananéia $\left(24^{\circ} 53^{\prime} \mathrm{S}, 47^{\circ} 50^{\prime} \mathrm{W}\right)$, Pariquera-Açu (243' $\left.\mathrm{S}, 47^{\circ} 53^{\prime} \mathrm{W}\right)$ and Piracicaba (22 $46^{\circ}$ 'S, $\left.47^{\circ} 49^{\prime} \mathrm{W}\right)$. In all the localities, the Cwa climate type prevails, according to the Köppen classification, characterized by moderate temperatures with hot summer (Prado 1997).

In spite of belonging to the same biome, the three forest fragments are different structurally: arboreal littoral vegetation ("restinga") (Cananéia) where predatory and clandestine exploitation of wood and palm heart opportunely occurs, semideciduous seasonal forest (Piracicaba), and dense ombrophylous forest (Pariquera-Açu), an area of environmental protection belonging to the Agronomic Institute of Campinas (IAC). The sampling follows the methodology described in Macedo et al. (2006).
Formicidae were identified in the Myrmecologia Laboratory of the Cacau Research Center (CEPEC/CEPLAC), Ilhéus, BA, where a reference collection was deposited under the registration number $\# 5395$. The nomenclature follows Bolton (2003).

The ants were grouped into guilds, based on ecological attributes of behavior and habitavailable on each species, and follow Delabie et al. (2000) and Silvestre et al. (2003).

\section{RESULTS AND DISCUSSION}

The ant species were grouped into nine guilds based on ant morphology and of the nest type and following Delabie et al. (2000) and Silvestre et al. (2003), except the new guild: "granivorous species" (Table I).

The guilds found in the forest fragments of Piracicaba, Pariquera-Açu and Cananéia were: litter omnivorous and scavengers, granivorous species, specialist predators living in litter and soil, litter generalist predators, subterranean mealybug-dependent species, army ants, dominant or subdominants arboreal, that occasionally forage on the ground, soil or litter dominant and fungus-growers, using feces and insect body fragments (Table I).

Some genera observed in this study (Table I), but not mentioned in Delabie et al. (2000) and Silvestre et al. (2003), were included in the guilds based on their biology and behavior. Some species of the genera Adelomyrmex, Basiceros, Lachnomyrmex, Pheidole, Rogeria, Solenopsis, as well as the genus Hylomyrma were framed in the litter omnivorous and scavengers guild; some species of Pheidole and Solenopsis in that of the granivorous species since large individuals ("soldiers") showed strong mandibles generally reliable to seed collect and processing; Amblyopone, Carebara, Discothyrea, Eurhopalothrix, Octostruma, Oxyepoecus, Proceratium and Typhlomyrmex in that of the specialist predators living in litter and soil; Acanthostichus is included in the guild of army ants and army-ant like species due to its cryptic mode of hunting; Camponotus was also included in the soil or litter dominant category. Acropyga was framed in that of subterranean mealybug-dependent species; Heteroponera as litter generalist predators ants.

The arboreal "restinga" (Cananéia) and seasonal semideciduous forest (Piracicaba) ecosystems presented eight guilds each, except for, respectively, the army ant and armyant like species guild and the subterranean mealybugdependent species. The dense ombrophylous forest ecosystem (Pariquera-Açu) presented six guilds, army ants and army-ant like species, subterranean mealybug-dependent species and dominant or subdominant arboreal ants, which occasionally forage on the ground not being found (Fig. 1). The number of guilds followed the same tendency as the richness of species in each ecosystem, which was higher in semideciduous seasonal forest $(n=45)$, followed by arboreal "restinga" and dense ombrophylous forest ( $\mathrm{n}=37$ and 36 respectively).

The specialist predators living in litter and soil guild guild was found in all of the ecosystems, comprising $36.7 \%$ of the 
Table I. Classification of ant species by guild, collected in fragments of Atlantic Forest of São Paulo, between March 2002 and March 2003 . The clasification follows Delabie et al. 2000 and Silvestre et al. 2003.

\begin{tabular}{|c|c|}
\hline Guilds & Species \\
\hline 1. Litter omnivorous and scavengers & $\begin{array}{l}\text { - Adelomyrmex longinodus Fernandez \& Brandão, 2003, Adelomyrmex sp. 1, Basiceros } \\
\text { disciger Mayr, 1887, Hylomyrma reitteri (Mayr, 1887), Lachnomyrmex plaumanni } \\
\text { Borgmeier, 1957, Megalomyrmex silvestrii Wheeler, 1909, Pheidole spp. (some species), } \\
\text { Rogeria pellecta Kempf, } 1963 \text { and Solenopsis spp. (some species) }\end{array}$ \\
\hline 2. Granivorous species & - Pheidole spp. (alguns) and Solenopsis spp. (some species) \\
\hline 3. Specialist predators living in litter and soil & $\begin{array}{l}\text { - Amblyopone armigera Mayr, 1887, Amblyopone lurilabes Lattke, 1991, Carebara } \\
\text { panamensis (Wheeler, 1925), Discothyrea sexarticulata (Borgmeier, 1954), Discothyrea } \\
\text { spp., Eurhopalothrix sp. prox. bruchi, Basiceros iheringi (Emery, 1888), Basiceros } \\
\text { petiolata (Mayr, 1887), Basiceros sp. 1, Oxyepoecus sp. 1, Proceratium brasiliense } \\
\text { Borgmeier, 1959, Strumigenys denticulata (Mayr, 1887), Strumigenys tanymastax (Brown, } \\
\text { 1964), Strumigenys sp. 1, Strumigenys dyseides Bolton, 2000, Strumigenys silvestrii } \\
\text { Emery, 1906, Strumigenys sphatula Lattke \& Goitia, } 1997 \text { and Typhlomyrmex major } \\
\text { (Santschi, 1923) }\end{array}$ \\
\hline 4. Litter generalist predators & $\begin{array}{l}\text { - Anochetus sp. 1, Gnamptogenys striatula (Mayr, 1883), Heteroponera microps } \\
\text { Borgmeier, 1957, Hypoponera foreli Mayr, 1887, Hypoponera spp. and Pachycondyla } \\
\text { striata Smith, F. } 1858\end{array}$ \\
\hline 5. Subterranean mealybug-dependent species & - Acropyga sp. 1 \\
\hline 6. Army ants & - Acanthostichus quadratus (Emery, 1895) \\
\hline $\begin{array}{l}\text { 7. Dominant or subdominants arboreal, that occasionally } \\
\text { forage on the ground }\end{array}$ & - Crematogaster sp. 1 \\
\hline \multicolumn{2}{|l|}{ 8. Soil or litter dominant } \\
\hline 8.1. Predators & - Odontomachus spp. \\
\hline 8.2. Omnivorous & $\begin{array}{l}\text { - Brachymyrmex, Camponotus (Myrmaphaenus) sp. 1, Linepithema sp. 1, Paratrechina } \\
\text { fulva (Mayr, 1862), Paratrechina spp., Wasmannia auropunctata (Roger, 1863) and } \\
\text { Wasmannia sigmoidea (Mayr, 1883) }\end{array}$ \\
\hline $\begin{array}{l}\text { 9. Fungus-growers, using feces and insect body } \\
\text { fragments }\end{array}$ & $\begin{array}{l}\text { - Apterostigma sp. comp. pilosum, Cyphomyrmex bigibbosus (Emery, 1894), } \\
\text { Cyphomyrmex peltatus Kempf, 1966, Cyphomyrmex salvini Forel, 1899, Cyphomyrmex } \\
\text { transversus Emery, } 1894 \text { and Sericomyrmex sp. } 1\end{array}$ \\
\hline
\end{tabular}

species found in the arboreal "restinga", $18.9 \%$ in the seasonal semideciduous forest and $22.7 \%$ in the dense ombrophylous forest. Those were followed by the soil or litter dominant guild, with $13.3,27.0$ and $18.2 \%$ of the species found in the same habitats, respectively. The subterranean mealybug-dependent species guild was only observed in the arboreal "restinga", corresponding to only $3.3 \%$ of the ants found in this ecosystem. The guilds of army ant and armyant like species and the dominant or subdominant arboreal ants, which occasionally forage on the ground, were evidenced only in the seasonal semideciduous forest, both making up $2.7 \%$ of the ants found in this ecosystem (Fig. 1).

The fact of the semideciduous seasonal forest ecosystem presenting the highest guild numbers and higher richness of species suggests that it would be due to the higher complexity of the vegetative structure, since that ecosystem maintains well developed and relatively closed vegetation, there existing, therefore, higher microhabitat availability for the ants. In the closed arboreous "restinga", as predatory and clandestine exploitation of wood and palm heart occurs, the trees were in their initial ecological succession stage, not presenting a defined canopy. Besides, the "restinga" vegetation characteristically increases in sandy soils, which do not allow the development of a particularly diverse plant biota (Fernandes 1998). A discontinuous canopy associated with

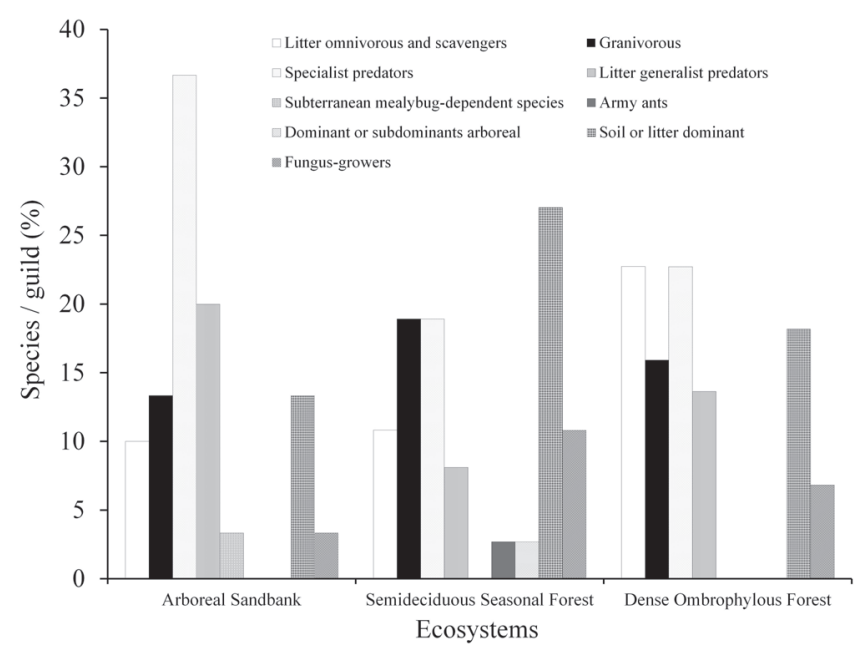

Fig. 1. Percent (\%) of guilds in relation to the number of species in arboreal sandbank, semideciduous seasonal forest and dense ombrophylous forest ecosystems, between March 2002 and March 2003.

the vegetation in the ecological succession stage was also observed in the dense ombrophylous forest remnant. As a consequence, the last two fragments can have suffered stronger environmental disturbances than the semideciduous seasonal forest ecosystem, which is visible particularly in 
the contribution of each ant guild (Fig. 1). According to Majer et al. (1984), there is a correlation between ant and plant richness, and the occurrence of certain plants facilitate area recolonization processes by ants. That is particularly important because many forest species found in the studied ecosystems possess an extremely developed root system growing in the superficial horizon of the soil. According to Delabie \& Fowler (1995) and Delabie et al. (2000), the function of the ants in the plant root system, as well as in the litter, is still poorly known, but there are no doubt that some species have a fundamental role in the forest soil regeneration process (i.e., mechanical action on soil nutrients and mineral incorporation, rotten vegetal material fractionation, water circulation, etc), as well as those under cultivation.

\section{ACKNOWLEDGMENTS}

This work was supported by Conselho Nacional de Desenvolvimento Científico e Tecnológico (CNPq) and by Fundação de Amparo à Pesquisa do Estado de São Paulo (FAPESP). "JHCD aknowledges his research grant from CNPq.

\section{REFERENCES}

Andersen, A. N. 1991. Responses of ground-foraging ant communities to three experimental fire regimes in a savanna forest of tropical Australia. Biotropica 23: 575-585.

Andersen, A. N. 1992. Regulation of momentary diversity by dominant species in exceptionally rich ant communities of the Australian seasonal tropics. American Naturalist 140: 401-420.

Andersen, A. N. 1997. Function groups and patterns of organization in North American ant communities: a comparasion with Australia. Journal of Biogeography 24: 433-460.

Beeby, A. 1993. Applying ecology. London, Chapman \& Hall, 441 p.

Bestelmeyer, B. T. \& J. A. Wiens. 1996. The effects of land use on the structure of ground-foraging ant communities in the Argentine Chaco. Ecological Applications 6: 1225-1240.

Bolton, B. 2003. Synopsis and classification of Formicidae. Memoirs of the American Entomological Institute 71: 1-370.

Brandão, C. R. F.; R. R. Silva \& J. H. C. Delabie. 2009. Formigas (Hymenoptera), p. 323-369. In: A. R. Panizzi \& J. R. P. Parra (eds). Bioecologia e Nutrição de Insetos. Base para o Manejo Integrado de Pragas. Brasília, Embrapa Informação Tecnológica, 1263 p.

Delabie, J. H. C.; D. Agosti \& I. C. Nascimento. 2000. Litter and communities of the Brazilian Atlantic rain forest region. p. 1-17. In: D. Agosti; J. D. Majer; L. T. Alonso \& T. Schultz (eds). Sampling Ground-dwelling Ants: Case Studies from the World's Rain Forests. Curtin University, School of Environmental Biology (Bulletin, 18), xii+75 p.

Delabie, J. H. C.; V. R. L. M. Paim; I. C. Nascimento; S. Campiolo \& C. S. F. Mariano. 2006. As formigas como indicadores biológicos do impacto humano em manguezais da costa sudeste da Bahia. Neotropical Entomology 35: 602-615.
Delabie, J. H. C. \& H. G. Fowler. 1995. Soil and litter cryptic ant assemblages of Bahian cocoa plantations, Pedobiologia 39: 423-433.

Elton, C. S. 1927. Animal ecology. New York, Macmillan, 207 p.

Fernandes, A. 1998. Fitogeografia Brasileira. Fortaleza, Multigraf, 340 p.

Lawton, J. H.; D. E. Bignell.; B. Bolton; G. F. Bloemers; P. Eggleton; P. M. Hammond; M. Hodda; R. D. Holt; T. B. Larsen; N. A. Mawdsley; N. E. Stork; D. S. Srivastava \& A. D. Watt. 1998. Biodiversity inventories, indicator taxa and effects of habitat modification in tropical forest. Nature 391: 72-76.

Louzada, J. N. C.; N. M. Sanches \& M. N. Schlindwein. 2000. Bioindicadores de qualidade e de impactos ambientais da atividade agropecuária. Informe Agropecuário 21: 72-77.

Macedo, L. P. M.; E. Berti Filho \& J. H. C. Delabie. 2006. Diversidade de formigas edáficas (Hymenoptera: Formicidae) associadas a Euterpe edulis von Martius (Arecaceae), em diferentes formações vegetais do bioma Mata Atlântica em São Paulo, Brasil. Revista de Agricultura 81: $55-70$.

Majer, J. D. 1981. The role of invertebrates in bauxite mine reabilitation. Peth: Forests Department of Western Australia. (Bulletin, 93), 29 p.

Majer, J. D. 1983. Ants: bioindicators of mine site rehabilitation, land use and land conservation. Environmental Management 7: 375-383.

Majer, J. D. 1992. Ant recolonization of rehabilitated bauxite mines of Poços de Caldas, Brazil. Journal of Tropical Ecology 8: 97-108.

Majer, J. D. 1996. Ant recolonization of rehabilitated bauxite mines at Trombetas, Pará, Brazil. Journal of Tropical Ecology 12: 257-273.

Majer, J. D.; J. E. Day; E. D. Kabay \& W. S. Perriman. 1984. Recolonization by ants in bauxite mines rehabilitated by a number of different methods. Journal of Applied Ecology 21: 355-375.

Prado, H. 1997. Os solos do Estado de São Paulo: mapas pedológicos. Piracicaba, ESALQ, 205 p.

Ramos, L. S.; C. G. S. Marinho; R. Zanetti; J. H. C. Delabie \& M. N. Schlindwein. 2003. Impacto de iscas formicidas granuladas sobre a mirmecofauna não-alvo em eucaliptais segundo duas formas de aplicação. Neotropical Entomology 32:231-237.

Root, R. B. 1967. The niche exploration pattern of the blue-grey gnatcatcher. Ecological Monographs 37: 317-350.

Silva, R. R. \& C. R. F. Brandão. 2010. Morphological patterns and community organization in leaf-litter ant assemblages. Ecological Monographs 80: 107-124.

Silvestre, R.; C. R. F. Brandão \& R. R. Silva. 2003. Grupos funcionales de hormigas: el caso de los grêmios del cerrado, p.113-148. In: F. Fernández (ed.). Introducción a las hormigas de la región Neotropical. Bogotá,, Instituto de Investigación de Recursos Biológicos Alexander von Humboldt, $x x v+424 \mathrm{p}$.

Vasconcelos, H. L. 1999. Effects of forest disturbance on the structure of ground-foraging ant communities in Central Amazonia. Biodiversity and Conservation 8: 409-420.

Vasconcelos, H. L.; Carvalho, K. S. \& J. H. C. Delabie. 2001. Landscape modifications and ant communities, p.199-206. In: R. O. Bierregaard Junior; C. Gascon \& T. E. Lovejoy (eds). Lessons from Amazonia: the ecology and conservation of a fragmented forest. New Haven, Yale University Press, 478 p.

Wilson, E. O. 1987. Causes of ecological success: the case of the ants. Journal of Animal Ecology 56: 1-9.

York, A. 1994. The long-term effects of fire on forest ant communities: management implications for the conservation of biodiversity. Memoirs of the Queesland Museum 36: 231-239. 